\title{
Design the Future Activities (DFA): A Pedagogical Content Knowledge Framework in Engineering Design Education
}

\section{Hadi Ali, Arizona State University, Polytechnic campus}

Hadi studies the influence of the future of work on curricular innovation, with a focus on exploring the relationships between and among adaptability, risk taking and value making. In an effort to characterize engineering education as an (eco)system for creating value, Hadi's approach integrates analytical methods of data science to address changes in systems and society. More broadly, Hadi is interested in examining how engineering innovations mobilize social and economic change. He has graduate degrees in Aeronautics and Astronautics (space systems design, astrodynamics and propulsion), Electrical and Computer Engineering (artificial intelligence, fields and optics) and Engineering Education (design cognition and human communication inquiry) all from Purdue University. He also has an undergraduate degree in Mechanical Engineering (design) from the University of Jordan, and an undergraduate degree in Aeronautics and Astronautics from Purdue. He taught courses in use-inspired design at ASU and in transforming ideas to innovations at Purdue. Prior to joining ASU, Hadi worked at the University of Jordan as a facilitator for curricular change and design content instructor at the Department of Mechatronics. He was on the management team of the Amman Design Week in its inaugural year in Jordan, launched by Queen Rania-a pioneering platform that harnessed creativity, revived the conversation about design, and instilled a spirit of collaboration and exchange.

\section{Prof. Andrew David Maynard, Arizona State University}

Andrew Maynard is a scientist, author, and a leading thinkers on socially responsible and ethical innovation. As Director of the ASU Risk Innovation Lab, he is working at the boundaries of how we think about risk and learn to succeed as we develop increasingly complex technologies.

Andrew's work spans both emerging and converging technologies, from nanotechnology and synthetic biology to autonomous vehicles, neurotechnologies and artificial intelligence. A professor in the ASU College of Global Futures (where he is Associate Dean of Curricula and Student Success) he brings a transdisciplinary approach to problem solving that combines the natural and social sciences with the arts and humanities, to explore new ways of collectively building a better future. 


\title{
Design the Future Activities (DFA): A Pedagogical Content Knowledge Framework in Engineering Design Education
}

\begin{abstract}
We propose an effective, innovative framework for developing content for design activities that address the challenges of the future where emerging technologies play a central role. Although engineering education research is concerned with preparing future engineers, the integration of future trends in technology with the engineering curriculum has been limited. We propose the Design the Future Activities (DFA) as a framework for systematically identifying and integrating emerging areas of research and technologies, such as artificial intelligence, into the teaching of engineering design. The core of developing and delivering the DFA framework is the teaching of the technology of artificial intelligence (AI). Because these technologies will change the nature of the future, we seek to engage with the ongoing discourse on the relationship between content (for design education) and pedagogy, through a proposed pedagogical content knowledge conceptual framework. Through a scholarship of integration that breaks the boundaries between disciplines, we propose a three-level framework: (1) Understanding technology analysis and system integration (to allow students to identify appropriate solutions given new technologies); (2) Making a value chain (or how these are appropriate solutions); and (3) Developing responsible innovations (or why these are appropriate solutions). While engineers continue to be creators and influencers of such technologies, the lack of understanding of the impact of their own technologies continues to cause an imbalanced innovation landscape, in education and in the workplace. We conclude that a new design approach to the engineering curriculum should be attempted, assuming that educators will systematically anticipate the future and recalibrate the curriculum.
\end{abstract}

\section{Introduction}

Contemporary approaches to engineering have been at the heart of technological progress since the earliest days of the industrial revolution, and the principles and practices they are built on extend back thousands of years. It's tempting therefore to assume that the foundations on which current engineering education is based are as relevant now as they have been in the past. Yet a number of social, economic and technological factors are conspiring to call into question the robustness of these foundations as we look to the future, and are indicating that a pivotal shift in thinking is needed as we examine how best to prepare the engineers of the future.

The term "engineering" has long been associated with the process of "building" or "constructing," often drawing on observational insights, accumulated knowledge, and science-based theories and models. More specifically, it has encompassed the idea of building or constructing with purpose, and usually (but not exclusively) the betterment or improvement of people's lives. As a result, engineering is a field of study and practice that is defined by both measurable outcomes and social benefits.

These elements: the applied use of knowledge and understanding; building products with purpose; measurable outcomes; and social benefits; form the foundations of many engineering education programs. And they have served graduates of these programs well in the past. However, as the coupling between technology development and societal impacts becomes increasingly tight, and the geographical, social and economic domains within which engineers operate become ever-more constrained, there are indications that these foundations need a substantial overhaul if the engineers of the future are able to operate successfully in a rapidly changing world. And pivotal to this overhaul will be better-understanding the relationship between engineering, society, and the future. 
For roughly ten thousand years, human ingenuity has been a source of innovation that has led to increases in quality of life. But it's also been a dominating factor in events and trends that have threatened quality of life. Advances from agriculture, energy-harnessing and civic infrastructure, through to synthetic chemistry, biotechnology, solid state engineering, bioengineering, and computer science, have positively transformed the world we inhabit. Yet with each wave of innovation there has been a backwash of consequences that have, in turn, required further innovation to overcome. As a result, nearly every significant challenge we currently face as a society, from climate change and global pollution, to the prevalence and spread of diseases and social disparities, can be traced to past engineering solutions.

Although somewhat simplistic, it can be surmised that current approaches to engineering education are based on a negative feedback model which assumes that "engineering solution space"- the conceptual space within which engineers operate - is dynamic, and that engineering solutions to emergent challenges arise sufficiently rapidly to damp down and ultimately reduce to the point of insignificance the long-term adverse consequences of actions taken. This is a model that has worked well in the past. But it is one which depends on three factors in particular to succeed: (i) engineering innovation time scales being substantially shorter than those associated with emergent consequences; (ii) loose coupling between applied solutions and emergent challenges; and (iii) minimal resource constraints. All three are interconnected, and all three are increasingly in question.

Firstly, the ability to damp down adverse consequences from the implementation of engineering solutions requires the process of coming up with new solutions to emergent problems to be far faster than the emergence of the problems themselves. As with any coupled system, the closer the characteristic time scales are between new capabilities and adverse consequences, the greater the likelihood of poorly controlled resonances between cause and effect, or runaway effects. And there are growing indications that the time scales between engineering causes and effects are becoming increasingly close.

This type of potentially harmful feedback loop is further exacerbated by the second factor: the nature of the coupling between engineering solutions and emergent consequences. Here, shifting social, economic and political norms and landscapes are increasing the tightness of the coupling between engineering solutions and social/economic/environmental consequences in ways that threaten to destabilize the relationship. In the past, the relatively slow speed with which ideas spread and were picked up and acted on around the world, meant that there was more time to iterate around dynamic engineering solutions to complex challenges. However, with the growth of the internet, social media, and a rapidly changing global sociopolitical landscape, the connections between engineering solutions (or even speculative solutions) and social consequences, are increasingly tight. The result is feedback systems that are in danger of becoming highly unstable without a sophisticated understanding of the sociopolitical landscape that modern engineering is a part of.

These feedback systems are further impacted by the third factor: resource constraints. There is an old saying that "dilution is the solution to pollution" meaning that, where resources are large enough to easily absorb adverse outcomes, those outcomes can easily be minimized. However, where the material outcomes of a course of action are comparable to resources within the system they occur in, and those resources are not "disposable," this solution to burying adverse outcomes is no longer an option-if it ever was.

The analogy extends to any system where resources are constrained, and actions have a sizeable impact on them. From an engineering perspective, we live on a planet where an increasing number of resources are highly constrained compared to our demands on them across many dimensions, from the air we breath, the land we live on and the oceans we rely on, to the highly complex biological, geological, social, economic and political systems we depend on. As a result, small perturbations in how we act in the present can have profound impacts on the future. 
The increasing significance of these three factors - time scales, coupling, and resource constraints - and the complex interplays between them, strongly suggests that we are approaching a tipping point where many of the assumptions on which modern engineering is based are in danger of becoming a liability, and that a comprehensive rethink with respect to how we train the engineers of the future is needed.

This will take far more than a deeper integration of engineering ethics into curricula-important as this is - or a greater emphasis on teaching foresight methodologies. It will require programs that provide a sophisticated understanding of the highly complex coupling between engineering, society and the future, and equip graduates with an ability to not only develop effective engineering solutions to pressing challenges and opportunities, but to be able to understand and respond to how these might play out in the future, and how to both prepare for this, and dynamically respond to unexpected outcomes. In other words, it will require all branches of engineering to incorporate aspects of systems engineering that look beyond technological capabilities to building resilient and sustainable social value within complex sociotechnical systems.

\section{Main argument of this work}

While the focus in the literature on change in engineering education has predominantly been on pedagogical change, equally important is the renewed emphasis on emerging new and key subject matter concepts, which impact engineering education broadly, and engineering design education specifically. Here, Pedagogical Content Knowledge (PCK) offers a unique approach to integrate content and pedagogy as it is relevant to engineering design education. The core of developing and delivering the DFA framework is the teaching of the technology of artificial intelligence (AI). Pedagogical content knowledge (PCK), originally conceptualized by Shulman $(1986 ; 1987)$, integrates the subject area of teaching (the "what") with useful forms of representation (the "how").

Although PCK has been a topic of research since the mid-1980s (Kind, 2009), its influence on the practice of education remains limited, largely due to the lack of a uniting paradigm - especially in the sciences and engineering (Abell, 2007; 2008). The presence of PCK in a variety of subject areas outside engineering (for example, in science, mathematics, English, communication, music, to name a few) is often combined with claims that it bridges subject matter (content knowledge) with effective instructional methods (pedagogical knowledge). In this context, Pedagogical Content Knowledge is considered a third major component of teaching expertise ("NARST", 2018). However, a "coherent theoretical framework" as originally proposed by Shulman (1986, p. 9), remains underdeveloped. Ball, Thames., \& Phelps (2008) made the following two observations regarding the lack of effective development of the PCK framework: first, no significant attention has been given to the specifics of content- "the very emphasis of the notion [of PCK]" (p. 3). Beyond making claims about teacher knowledge, connections between ideas from one subject matter to the other have not been adequately studied nor seriously addressed in order to effectively connect subject matter knowledge with pedagogical knowledge. Second, Ball et al. (2008) observed that research that utilized the PCK did so without substantive, research-based and identifiable content knowledge to test definitions and "develop measures of such knowledge" (p. 4).

There is an urgent need to re-examine how engineering curricula incorporate a deep understanding of the coupling between technology, society and the future that will equip future engineers to thrive in an engineering solutions space that is markedly different to that of the past. We propose the Design the Future Activities (DFA) to address this need. 


\section{The changing nature of design problems}

\subsection{Defining engineering design and complex engineering problems}

The general criteria for Student Outcomes (1) through (7) in accrediting engineering programs, 20202021, describe students' ability to identify, formulate, and solve complex problems with considerations of "public health, safety, and welfare, as well as global, cultural, social, environmental, and economic factors" ("ABET", 2019, p. 5). In addition, the Accreditation Board puts the responsibility on faculty in engineering programs to develop and implement experiences for students which integrate basic knowledge with communication and teaming skill development in contemporary areas of ethical, economic and social needs. The definitions that ABET provide for complex engineering problems and for engineering design are provided in Table 1.

Table 1. Terms definitions based on ABET criteria, 2020-2021 (“ABET”, 2019, p. 4)

\begin{tabular}{|c|c|}
\hline Term & Meaning \\
\hline Complex Engineering Problems & $\begin{array}{l}\text { "Complex engineering problems include one or more of the following } \\
\text { characteristics: involving wide-ranging or conflicting technical issues, having } \\
\text { no obvious solution, addressing problems not encompassed by current } \\
\text { standards and codes, involving diverse groups of stakeholders, including many } \\
\text { component parts or sub-problems, involving multiple disciplines, or having } \\
\text { significant consequences in a range of contexts." }\end{array}$ \\
\hline Engineering Design & $\begin{array}{l}\text { "Engineering design is a process of devising a system, component, or process } \\
\text { to meet desired needs and specifications within constraints. It is an iterative, } \\
\text { creative, decision-making process in which the basic sciences, mathematics, } \\
\text { and engineering sciences are applied to convert resources into solutions. } \\
\text { Engineering design involves identifying opportunities, developing } \\
\text { requirements, performing analysis and synthesis, generating multiple solutions, } \\
\text { evaluating solutions against requirements, considering risks, and making trade- } \\
\text { offs, for the purpose of obtaining a high-quality solution under the given } \\
\text { circumstances. For illustrative purposes only, examples of possible constraints } \\
\text { include accessibility, aesthetics, codes, constructability, cost, ergonomics, } \\
\text { extensibility, functionality, interoperability, legal considerations, } \\
\text { maintainability, manufacturability, marketability, policy, regulations, schedule, } \\
\text { standards, sustainability, or usability." }\end{array}$ \\
\hline
\end{tabular}

\subsection{Traditional content for engineering design}

Engineering design has constantly been associated with problem-solving (De Luca, 1991), with a shift in the engineering curriculum from its disciplinary-focus to its process-focus (Savage \& Sterry, 1990). The notion that engineering design has a unique content continues to be debated (Lewis, 2005), especially when identifying criteria for accrediting engineering programs. Without concrete structure, calls have been made to integrate engineering design with mathematics and applied science (Roman, 2001) and as a research activity (Neumann, 2003). One approach to integrate engineering design with science was proposed through a three-phase pedagogical approach of (1) exploring; (2) introducing a standard model; and (3) improving of the standard model (Zubrowski, 2002).

The work by Westberry (2003) exemplified early attempt to recognize the varying nature of design activities which requires different teaching modalities. At the center of all views of engineering design is the notion of human creativity and imagination (Koen, 1994). However, this notion for solving problems continued to be codified in a structured approach that can be applied without specific attention to emerging subject matter (Pahl \& Beitz, 1996) but with the key element of abstract representation (Ali \& McKenna, 2020; Dym, 1994a). At the same time, engineering design was recognized to have evolving 
strategies (Cross, 2000). While some view engineering and design to be synonymous in engineering education (McMasters \& Ford, 1990), the actual content and rigor of design in the engineering curriculum, compared to the applied science topics, continues to be a contentious area (Dym, 1994b). Although advances in engineering design teaching and learning have been made (Dym et al., 2005), one of the reasons for the lack of high priority in developing content for engineering design is what some claim that "creativity cannot be taught" and that "design lacks the rigor of science" in terms of precision, progression, and consequently, pedagogic conditions (West, Flowers \& Gilmore, 1990; Peterson, 1990).

\subsection{The emerging shift in engineering design}

Design for the future should embrace the notion that users and customers will be intelligent, autonomous objects (Autor, Mindell, \& Reynolds, 2019). Consider the possibilities afforded by objects that connect knowledge, talent, and systems to create value. A number of example objects, potential applications and enabling technologies are listed in Table 2. The focus for designing for the future has shifted from the focus on products to processes (Blank, 2013) to the delivery of value (Ali \& Lande, 2019; Keeley, et al., 2013). In parallel to changing trends, education has similarly shifted from a focus on products (Dym, et al., 2005) to processes (Diefes-Dux, et al., 2004) and to the integration of entrepreneurship into the curriculum (Kuratko, 2011; London, et al., 2018). However, while the importance of centering the design effort of students around customer discovery and value creation is increasingly being recognized (e.g., Bekki, et al., 2018), challenges exist in effectively integrating content that students learn in the engineering curriculum, and advances in technology, with ways of values to a customer in an education setting. A primary challenge is the development of new content which builds on, supplements and expands students' grasp of engineering, economic and social concepts. Furthermore, the integration of new content into an already packed curriculum, while providing the necessary support for implementation - including training of the instructional team-poses a significant challenge for the delivery of a high-quality learning experience for students. Finally, managing assessment of students' designs in a structured and meaningful way, in addition to their understanding of the new content on technologies of the future, can be problematic.

Here, we believe that the authenticity of the experience is a key; that is, providing structured design experiences that integrate realistic context of the technologies of the future with meaningful contexts that match and build on students' engineering ability and general knowledge.

Table 2. Examples of emerging designs, their applications, and their enabling technologies that are changing the nature of design for the future.

\begin{tabular}{|c|c|c|}
\hline $\begin{array}{c}\text { Example of intelligent, autonomous } \\
\text { objects }\end{array}$ & Potential applications & Enabling technologies \\
\hline $\begin{array}{l}\text { - Social robots } \\
\text { - Service robots } \\
\text { - } \text { Collaborative robots } \\
\text { - Robot arms } \\
\text { - Lrones } \\
\text { - Aifestyle robots } \\
\text { Autonomous vehicles }\end{array}$ & $\begin{array}{ll}\text { - } & \text { Public health service } \\
\text { - } & \text { Medicine } \\
\text { - } & \text { Agriculture } \\
\text { - } & \text { Building cleaning } \\
\text { - } & \text { Retail trade } \\
\text { - } & \text { Production } \\
\text { - } & \text { Monitoring } \\
\text { - } & \text { Shopping } \\
\text { - } & \text { Delivery } \\
\text { - } & \text { Cooking } \\
\text { - } & \text { Training } \\
\text { - } & \text { Transport }\end{array}$ & $\begin{array}{ll}\text { - } & \text { Big data } \\
\text { - } & \text { In-memory data } \\
& \text { analytics } \\
\text { - } & \text { Gesture recognition } \\
\text { - } & \text { Brain waves monitoring } \\
\text { - } & \text { Voice recognition } \\
\text { - } & \text { Hearable computing } \\
\text { - } & \text { Internet of things } \\
\text { - } & \text { Blockchain technology }\end{array}$ \\
\hline
\end{tabular}




\section{Framework development of DFA}

\subsection{Underlying theoretical framework}

Pedagogical content knowledge (PCK), originally conceptualized by Shulman (1986; 1987), integrates the subject area of teaching (the "what") with useful forms of representation (the "how"). Built on the formulation by Fenstermacher (1986) that an instructor knows something that is wished to be understood by others, the teacher works on transforming understanding by engaging students through effective pedagogical approaches that are suitable for the content to be understood. The issues of the representation of ideas and the ability of the educator to represent ideas in a multitude of ways are central in the conceptualization of PCK. According to Shulman (1987), the ability to represent ideas and, in the process, blending between the understanding of content and its organization and the understanding of how content can be represented and adopted for instructions, is what "distinguish[es] the understanding of the content specialist from that of the pedagogue" (p. 8). Shulman (1987) suggested the categories in Table 3 to describe the knowledge base of the educator. Of particular interest is PCK and its relation, in design education, to the "management of ideas" in discourse and activities in design sessions (p. 1).

Table 3. Categories of knowledge base of an educator, as suggested by Shulman (1987).

\begin{tabular}{|l|l|}
\hline \multicolumn{1}{|c|}{ Category } & Description \\
\hline$\bullet \quad$ Content knowledge & $\begin{array}{l}\text { The subject matter that an educator understands and wishes } \\
\text { to transfer to students and transform their understanding } \\
\text { Broad principles of classroom organization that transcend } \\
\text { subject matter }\end{array}$ \\
\hline$\bullet \quad$ General pedagogical knowledge & $\begin{array}{l}\text { Grasp of materials and programs that colleague educators } \\
\text { serve to the students }\end{array}$ \\
\hline - $\quad \begin{array}{l}\text { Knowledge of learners and their } \\
\text { characteristics }\end{array}$ & $\begin{array}{l}\text { Understanding of current knowledge states, skills, attitudes, } \\
\text { and values of the students } \\
\text { The workings of the academic program, the school, and the } \\
\text { larger cultural, social, and economic contexts }\end{array}$ \\
\hline $\begin{array}{l}\text { Knowledge of educational contexts } \\
\text { The philosophical and historical grounds of the educational } \\
\text { goals and process }\end{array}$ \\
\hline $\begin{array}{l}\text { "the special amalgam of content and pedagogy that is } \\
\text { purposes, and values }\end{array}$ \\
$\begin{array}{l}\text { Pedagogical content knowledge } \\
\text { of professional understanding" (p. 8) }\end{array}$
\end{tabular}

At the core of the PCK is the integration of content with the process of pedagogical reasoning and action (Ball, Thames \& Phelps, 2008; Gess-Newsome, 1999; Grossman, 1990). The educator's ability to explain and show should not be tacit knowledge. According to Shulman $(1986 ; 1987)$ an effective educator should be "held responsible for explaining what they do and why they do it, to their students, their communities, and their peers" (Shulman, 1987, p. 12). In design education, this involves the transitioning of the design educators from grasping the subject matter themselves so that they can elucidate it from the students "in new ways, reorganize and partition it, cloth it in activities and emotions, in metaphors and exercises, and in examples and demonstrations" (p. 13).

The emphasis in the development of the PCK framework is on transformative comprehension, reasoning and reflecting (Davis, 2003; Driel, Verloop \& Vos, 1998; Magnusson, Krajcik, \& Borko, 1999; Veal, Tippins \& Bell, 1998). The framework does not advocate for prescriptive ways for teaching for the transmission of facts and principles (Fenstermacher, 1978; 1986); instead, effective teaching in this framework provides grounds for students for choices and action (Green, 1971) - a fundamental aspect in design education. The framework views pedagogy as a process of exchange of ideas: a teacher grasps the content knowledge; is aware of how he or she "commuted from the status of learner to that of teacher" 
(Shulman, 1987, p. 12); and interacts with students' ideas to reach new understanding of both learning and teaching.

\section{Method}

In this paper, we use the scholarship of integration as a research method with the goal of making connections across diverse domains of knowledge given the nature of the problem we aim to tackle. The scholarship of integration was proposed by Boyer (1990) in a study that envisioned a more inclusive scholarship that moves beyond traditional, disciplinary approaches of university research. Design, as described before, has become a more sophisticated domain which requires attention to be paid to activities and progress in the technological domain. A singular, unidirectional approach to the development of the field, in terms of teaching and practice, will not reveal the full potential of what educators and researchers can bring to the classroom and the students' experience.

The scholarship of integration places emphasis on making connections, bringing in new perspectives to illuminate what we already know in a new light (Norman \& Schmidt, 1999). Engineering design, as discussed before, is increasingly becoming dependent on other areas of expertise. This is where the scholarship of integration can break boundaries between disciplines. According to the American Association of Higher Education, "Of the several forms of scholarly work, the scholarship of integration has received the least attention. It is this kind of intellectual work, however, that is most needed in the effort to improve undergraduate education, to make connections to the community, and, ultimately, to ensure the quality of research" ("AAHE", 2000). In the development of the DFA in this work, we attempt to integrate different domains of knowledge so that we can point to new, possible and relevant connections which will shape and support the development of new engineering design pedagogical content knowledge.

\section{Elements of DFA}

We propose the DFA as a three-level framework: (1) Understanding technology analysis and system integration (to allow students to identify what are appropriate solutions given the new technology); (2) Making a value chain (how are these appropriate solutions); and (3) Developing responsible innovations (why are these appropriate solutions). The framework is illustrated in Figure 1. In the following sections, we discuss each level by first describing the proposed content to explore the topic, then by suggesting effective pedagogy to deliver the relevant content. We attempt to underscore the special amalgam of content and pedagogy as conceptualized in the PCK framework. We also provide illustrative examples for the content at each proposed level. 


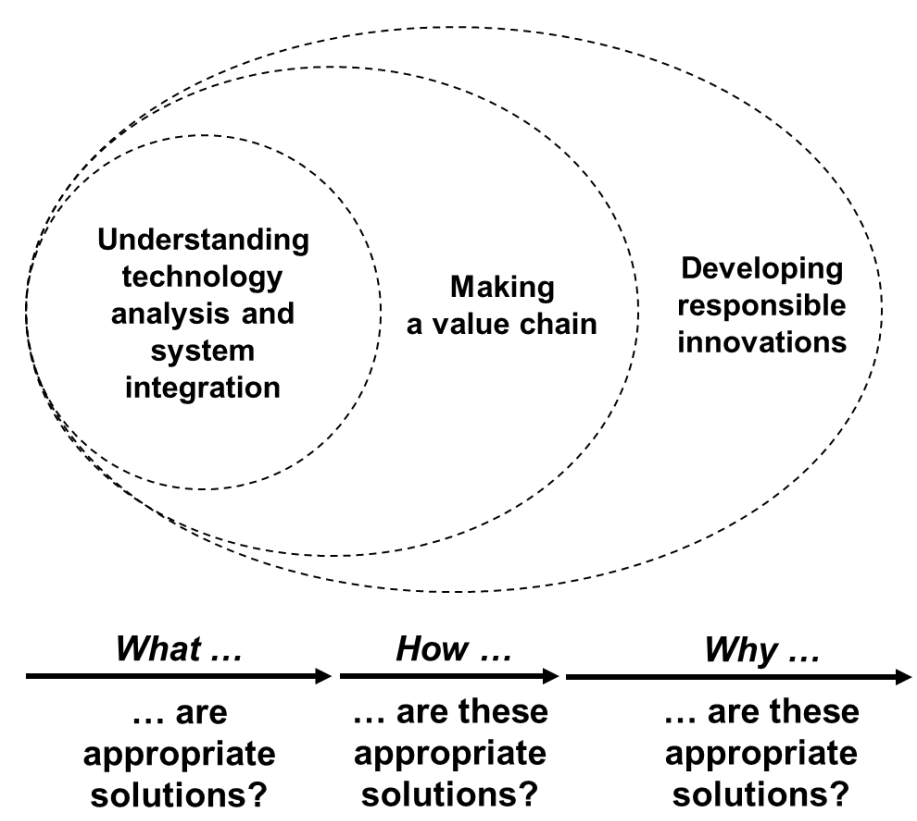

Figure 1. The Design for Future Activities (DFA) framework.

\subsection{Understanding technology analysis and system integration}

\section{$\underline{\text { Content }}$}

The core of developing and delivering the DFA framework is the teaching of the technology of artificial intelligence (AI). While there are many trends in technology innovation that are transforming the world we live in, AI presents a unique combination of disruptive potential and speed of adoption and growth. Lee (2018) has argued for the change, made by AI, on blue-collar jobs in the future, and the emerging competition in the area, with unexpected pace, between the United States and China. Although AI will not necessarily alter the employment landscape immediately (Malone; Rus; \& Laubacher, 2020), it will gradually and significantly change the way we do work (Rao; Palaci; \& Chow, 2019). As machines continue to be designed to think or act in ways that mimicking humans, and with increasing levels of rationality (Russell \& Norvig, 2020), designing for the future should aspire to take into account of the range and variety of potential increase in human capability due to emergent AI tools and techniques. Since its inception in the 1950s, the field of AI continues to be developed to create machines with humanlike abilities (Turing, 1950). Today, with the level of maturity of the field, the scope of its applications has stretched beyond specialized research in the field itself (Malone, 2018; Russell \& Norvig, 2020) to encompass the design of and innovation in new business ecosystems (Keeley, et al., 2013).

In this discussion, we delve deeper into the first dimension of our suggested framework by answering the question: how might we develop understanding of technology and system integration? First, consider the following illustrative case. A team of students are designing a drone delivery system that will deliver purchased items from the store of an online retailer to the home of a customer. Such a problem requires an understanding of multiple aspects of the technology involved; for example, means of transportation; sensing of space, weather and other environmental factors; information communication; item location, maps and updates of status; scheduling and delivery conditions. These are just some examples of the technical complexity of the problem. As soon as the system is embedded in a social context, challenges around social behavior come into play, such as traffic forecasts, safety issues, and perceptions of risks and threats - including to areas of value that are deeply important to individuals and communities (Maynard, 
2014; Maynard \& Garbee, 2019). Our argument in this paper is that there is a need in engineering design education research to systematically introduce emerging areas of research and technologies, which define human-machine partnership, in design settings. In Table 4, we highlight content to be developed to understand emerging technology and integration of systems, following the analysis provided by Malone et al. (2020). It is important to note that the concentric nature of activities, as illustrated in Figure 1, implies the overlapping nature of activities. The first level on Understanding technology analysis and system integration, for example, implies social awareness of the technology, for the third level.

The content on machine learning should develop understanding of, and ability to apply knowledge about, the state of art technology in supervised learning (i.e., labeling data for analysis); unsupervised learning (i.e., system's use of data without labels); and reinforcement learning (i.e., creating a reward system for successful utilization of data). The content on natural language processing should develop understanding of available text processing bots and software applications for establishing human-machine interactions in specific domains. The content on robotics should develop understanding of the potential application of robots in diverse areas such as medicine, transportation, agriculture and lifestyle, by designing machines use sensors to collect information, and use onboard interpretation algorithms to determine action. The content on computer vision should develop understanding of how visual information can be acquired and used for a variety of tasks such as object recognition, motion analysis and scene-based decisions. The content on systems thinking should develop the ability to delaminate boundaries between systems, Figure 2 , and interactions between systems, Figure 3, with the ultimate goal of optimizing interactions with minimal unintended consequences. The content on design thinking should develop the ability to focus on users and their needs with the use of tools such as radical collaboration, prototyping and experimentation to learn.

Table 4. Content topics for Understanding emerging technology and integration of systems level of the DFA.

\begin{tabular}{|c|c|c|}
\hline Topic & Content: Elements of the topic & $\begin{array}{l}\text { Sample } \\
\text { references }\end{array}$ \\
\hline Machine learning & $\begin{array}{l}\text { - Programming instruction to complete daily tasks } \\
\text { - } \quad \text { Programming machines to analyze data, learn from } \\
\text { experiences and take action } \\
\text { - } \quad \text { Programming machines to output algorithms for future action }\end{array}$ & $\begin{array}{l}\text { Russell \& } \\
\text { Norvig (2020) }\end{array}$ \\
\hline $\begin{array}{l}\text { Natural language } \\
\text { processing }\end{array}$ & $\begin{array}{l}\text { - Understanding tools for speech recognition, text } \\
\text { understanding and question answering }\end{array}$ & $\begin{array}{l}\text { Remus \& Levy } \\
\text { (2017); Xiong, } \\
\text { et al. (2018) }\end{array}$ \\
\hline Robotics & $\begin{array}{l}\text { - Understanding, developing and implementing of independent } \\
\text { machines movement and action } \\
\text { Designing robot manipulation mechanisms (e.g., force } \\
\text { exertion) } \\
\text { - Designing robot locomotion algorithms (e.g., perception, } \\
\text { planning, reasoning, learning and control) }\end{array}$ & Mountz (2011) \\
\hline Computer vision & $\begin{array}{l}\text { Developing algorithms to understand the physical world } \\
\text { through captured visual information }\end{array}$ & $\begin{array}{l}\text { Deng et al. } \\
(2009)\end{array}$ \\
\hline Systems thinking & $\begin{array}{l}\text { Develop the ability to think beyond simple systems to } \\
\text { consider boundaries and interaction between complex systems }\end{array}$ & $\begin{array}{l}\text { Schneider \& } \\
\text { Berenbach, } \\
\text { (2013) }\end{array}$ \\
\hline Design thinking & $\begin{array}{l}\text { Develop the ability to go through iterations of the design } \\
\text { thinking cycle of defining a point of view-ideating-- } \\
\text { prototyping-testing-understanding and observing }\end{array}$ & Dorst (2011) \\
\hline
\end{tabular}




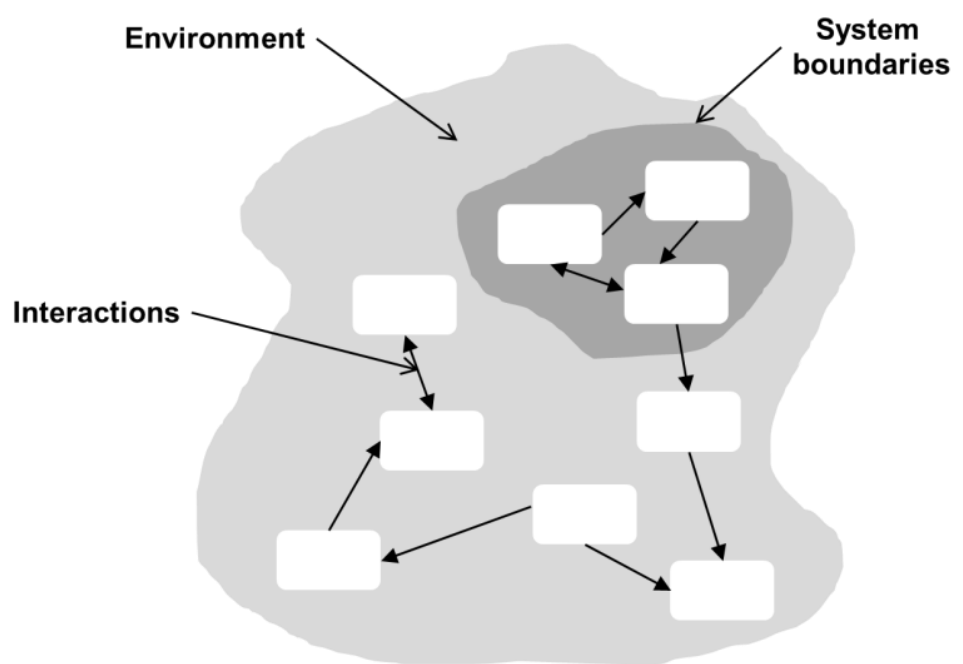

Figure 2. Mapping systems to reality requires the ability of effectively delimitating systems of interest by drawing boundaries for further modeling and development.
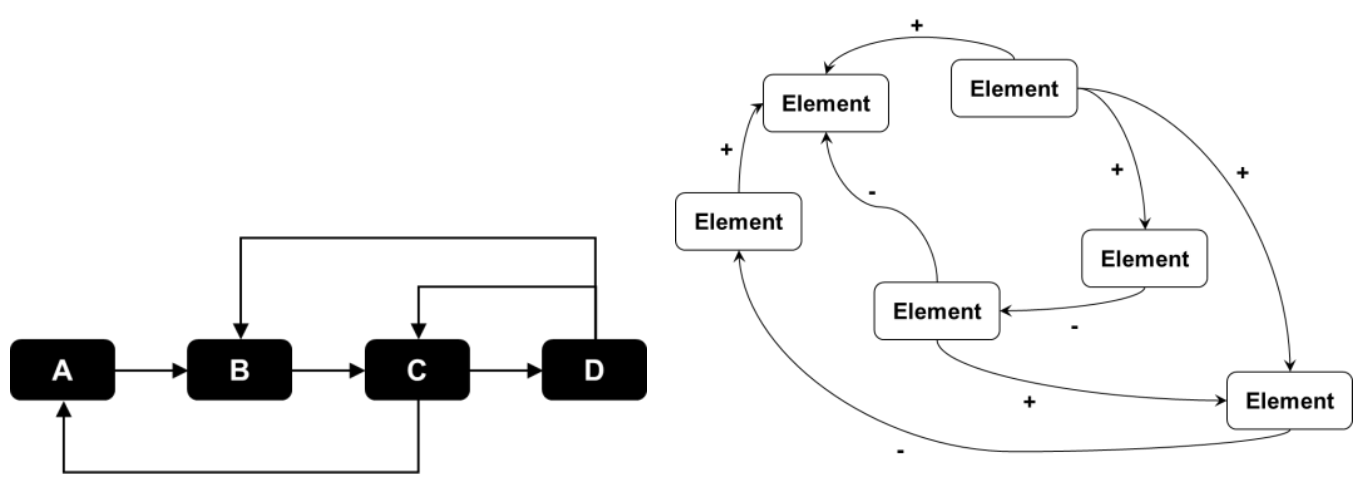

Figure 3. An example of a feedback loop (left) and causal loop (right) as essential tools for representing relationship connections between elements in systems thinking.

\section{Pedagogical content knowledge}

Inductive teaching methods that allows students to discover topics by active engagement with content are proposed. Inductive teaching methods are different from traditional, deductive teaching methods which rely merely on introducing theories and progression of applications. Integrating the subject area of teaching (the "what") with useful forms of representation (the "how") for developing the understanding of emerging technology and integration of systems can be achieved by effective knowing and utilizing of the inductive teaching and learning methods as follows:

- Problem-based learning: As a method that features ill-structured, open-ended problems, this method provides real-world contexts where students begin with the specific of situation (observations or data) to interpret, analyze and solve (Barrows \& Tamblyn, 1980; Boud \& Feletti, 1997). The method requires carefully defined sets of problems that engage students in a structured process to develop a higher level of learning (Dahlgren, 2003). Class time can be dedicated for mini lectures to help scaffolding the problem, class discussions or students reporting (Norman \& Schmidt, 1992; Weiss, 2003). Students learning in problem-based learning is selfdirected, with the instructor playing the role of a facilitator (a coach, or a "guide on the side") (Duch, Groh \& Allen, 2001; Tan, 2003) 
- Project-based learning: Project-based learning requires the development of a final artifact (design or a report) as the ultimate outcome of the process (de Graaff \& Kolmos, 2003). When carefully combined with problem-based learning, methods and skills acquired from solving problems can be transferred to the project's objective (Mills \& Treagust, 2003). Projects should center around the topics of interest (e.g. Table 4) require the acquisition of new knowledge, and be authentic in involving and responding to the complexity of the problems described here (Thomas, 2000).

\subsection{Making a value chain}

\section{$\underline{\text { Content }}$}

The next, higher level of developing and delivering the DFA framework is teaching around creating a value proposition that transcends simply the making of things. As the National Academy of Engineering articulated in the report Making Value for America: Embracing the Future of Manufacturing, Technology and Work: "'making things' can no longer be considered separate from the value chain, the system of research and development, product design, software development and integration, and lifecycle service activities performed to deliver a valuable product or service to market" ("NAE", 2015, p. 1). Designing for the complete value chain requires holistic understanding of returns of the innovation, interlinking activities and in-house capabilities.

A value chain (or value network) can be defined as the system of activities performed to create, deliver, and support a product through its entire life cycle (Porter, 1998). The global economic interconnectivity has resulted in an increase in competition to acquire different aspects of the globally distributed value chain for different innovation activities. Some of the factors contributing to the diversification and distribution of the value chain include: proximity to markets; proximity to raw materials ("NAE", 2015); cost, availability and reliability of energy ("EIA", 2021); labor costs (Baldwin \& Lopez-Gonzalez, 2013); and government regulations and policies (Plumer, 2013).

Here, we would argue that there is a need in engineering design education research to systematically introduce emerging areas of research and technologies, by engaging relevant content in order for students to have authentic design experiences. Consider the following illustrative example. A team of students is considering the development of a chat application for peer tutoring and networking amongst a cohort in a program. One path they can take is to iteratively test their proposed platform with all potential stakeholders in order to realize the full value proposition. An alternative, more effective approach, may be to systematically build an ecosystem, in which the application is designed for the complete value chain by moving from a "focused peer network" to a "decentralized ecosystem" (Figure 4). While programming the application (first level of the DFA framework) can be achievable, in order to fully establish the platform requires building a business ecosystem; that is, long-term relationships with different stakeholders that guarantees the livelihood of the platform beyond the current cohort and the current environment (second level of the DFA framework). In Table 5, we highlight content to be developed to making a value chain, following the framework developed by Keeley et al. (2013).

The content on making a value model should develop the ability to identify potential value generating streams, differences between competitors and collaborators models, and differences between norms and innovative offerings. The content on networking should develop the ability to take advantage of existing technologies and platforms, in a hyper-connected world, to strengthen the offering of the design. The content on configuring structure should develop the ability to distinguish between traditional and unique structures that drive in talent for the developing, functioning and operation of the proposed design. The content on configuring process should develop the ability to push beyond traditional methods of creating 
efficiency and overall producing of offerings around the proposed design. The content on product performance should develop the ability to identify uniqueness of design in terms of simplicity, sustainability, and customization. The content on product system should develop the ability to foster the modularity and interoperability of the proposed design. The content on service experience should develop the ability to identify and design ways that a customer interacts with the organization offering the design solution. The content on channels should develop the ability to identify different and complementary ways for directly or virtually offering the design solution. The content on branding should develop the ability to design distinct identity for the design that enables the creation of a community around the brand. The content on customer engagement should develop the ability to transform the complex task that a design accomplishes to an easy and engaging experience with the user.

\section{Pedagogical content knowledge}

Because the emphasis in the development of the PCK framework is on transformative comprehension, reasoning and reflecting, developing the making a value chain can be achieved by effective knowing and utilizing of the inductive teaching and learning methods as follows:

- Case-based teaching: As a method, case-based teaching engages students in historical or hypothetical situations to analyze decisions made and their consequences (Kardos \& Smith, 1979). The analysis of cases can involve problem diagnosis, solutions strategies, and interlocking interactions that may require attention to multiple factors (e.g., economic, social as well as technical). Development of authentic cases is a demanding process that requires taking into account both the background of students and the complexities of the problem (Lundeberg, Levin \& Harrington, 1999). Cases can be a complete narrative or a more engaging process that involves students' own made decisions (Lynn, 1999). According to Kardos (1979), analysis of cases can be based on the following steps: case reviewing; problem statement; information collection; alternatives development; alternatives evaluation; identifying a course of action; and evaluating solutions with potential comparing with actual case outcomes.

Table 5. Content topics for Making a value chain level of the DFA.

\begin{tabular}{|c|c|c|}
\hline Topic & Content: Elements of the topic & $\begin{array}{l}\text { Sample } \\
\text { references }\end{array}$ \\
\hline Making value model & $\begin{array}{l}\text { Learning how to sustain the design, its offering and its } \\
\text { organization while simultaneously creating value for } \\
\text { stakeholders (monetary or otherwise) }\end{array}$ & Picker (2010) \\
\hline Networking & $\begin{array}{l}\text { - Developing the ability to build relationships around the } \\
\text { design, through partnerships and affiliations }\end{array}$ & "Forbes" (2004) \\
\hline $\begin{array}{l}\text { Configuring } \\
\text { structure }\end{array}$ & $\begin{array}{l}\text { Developing the ability to organize talents and assets around } \\
\text { the proposed design }\end{array}$ & $\begin{array}{l}\text { Mourdoukoutas } \\
(2017)\end{array}$ \\
\hline Configuring process & $\begin{array}{l}\text { Developing the ability to create innovative ways of making } \\
\text { and delivering the design }\end{array}$ & Hansen (2012) \\
\hline $\begin{array}{l}\text { Product } \\
\text { performance }\end{array}$ & $\begin{array}{l}\text { - Developing the ability to provide distinguishable offering in a } \\
\text { competitive market or within unique circumstances }\end{array}$ & $\begin{array}{l}\text { Wade et al. } \\
(2019)\end{array}$ \\
\hline Product system & $\begin{array}{l}\text { Developing the ability to creating complementary products, } \\
\text { systems and services around the proposed design }\end{array}$ & $\begin{array}{l}\text { Krishnamurthy } \\
(2009)\end{array}$ \\
\hline $\begin{array}{l}\text { The service } \\
\text { experience }\end{array}$ & $\begin{array}{l}\text { - Developing the ability to support and amplify the way users } \\
\text { experience the design }\end{array}$ & $\begin{array}{l}\text { Knowles et al. } \\
(2020)\end{array}$ \\
\hline Channels & - $\quad$ Developing the ability to design delivery options to users & $\begin{array}{l}\text { Andersen \& } \\
\text { Pold (2014) }\end{array}$ \\
\hline Branding & $\begin{array}{l}\text { - Developing the ability to present and express design in a } \\
\text { distinct and relevant fashion }\end{array}$ & Norris (1993) \\
\hline $\begin{array}{l}\text { Customer } \\
\text { engagement }\end{array}$ & $\begin{array}{l}\text { - Developing the ability to create and sustain interactions } \\
\text { between the design and the user }\end{array}$ & Shontell (2015) \\
\hline
\end{tabular}




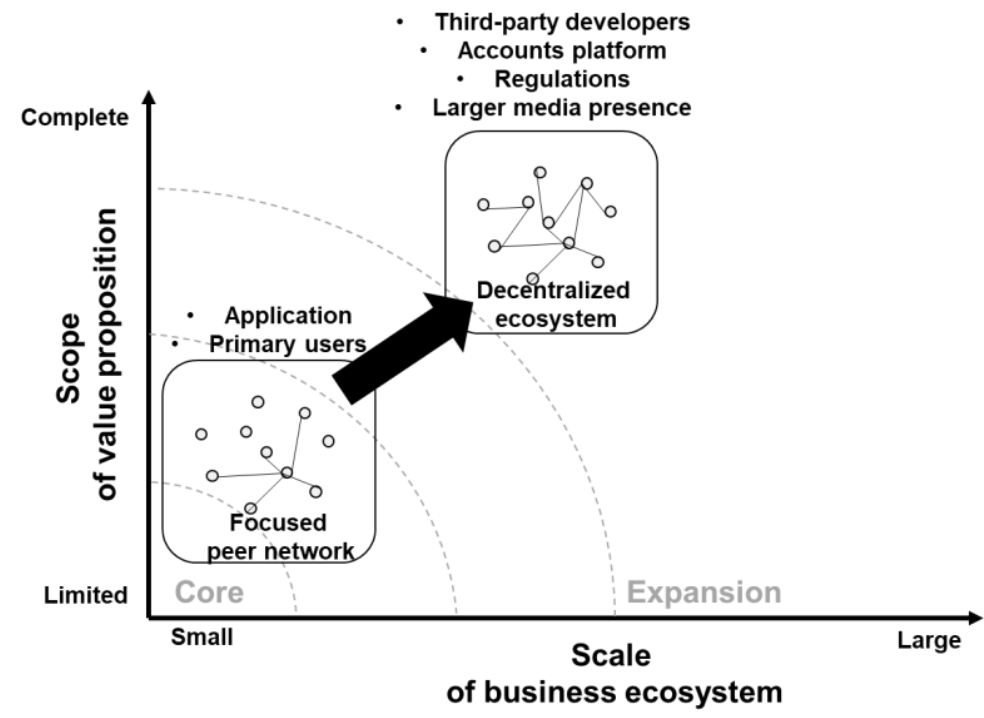

Figure 4. An example of developing a business, decentralized ecosystem from a focused peer networking application (in a potential student design problem). The example, as illustrated and discussed in the text, seeks to address the complete scope of the value proposition, the second aspect of the DFA.

\subsection{Developing responsible innovations}

\section{$\underline{\text { Content }}$}

This level of developing and delivering the DFA framework is concerned with exploring and grounding students in concepts related to attention to socially responsive and responsible innovation. While emerging technologies are driving value-growth in innovative ways, they also have the potential to adversely impact society and the environment in novel ways. And the more complex, interconnected and globalized social, technological and economic networks become, the greater the chances are of seemingly-positive innovations leading to serious harm (Maynard, 2014; Maynard \& Garbee, 2019). One aspect of the entrepreneurial approach to modern innovation is that top-down governance often lags behind it, and technology entrepreneurs sometimes seek to utilize this gap (Maynard \& Garbee, 2019). Some of the attributes of the innovative culture that focuses on new technologies include experimentation, risk-taking and collaboration (Delbecq \&Weiss, 2000; Harris \& Alter, 2014). However, with experimentation and risk-taking, there is a social responsibility to ensure that outcomes are as safe and as beneficial as possible (Perrow 1999; Taleb 2010).

Consider some of the following illustrative examples. Maynard (2014), for example, analyzed the case of $3 \mathrm{D}$ printing of an artificial mind, given the level of spatial resolution of 3D printing systems when combined with nano and AI technologies. The convergence of physical and digital technologies, in what has been coined as the "fourth industrial revolution," represents a plethora of challenges as the convergence between the two spans different aspects of the value chain (Schwab, 2015). More specifically, citizens are affected by the networking of such devices and their influence on life styles, privacy and overall well-being (Maynard, 2015).

According to Maynard (2015), the content on developing responsible innovation should foster effective multiple-stakeholder dialogues; encourage actionable empathy; develop foresighting capabilities; and continue to provide educational opportunities for stakeholders. More importantly, the content on developing responsible innovation should encourage students to consider transformative approach to risk- 
taking by exploring "innovative ways of thinking about and addressing emerging risks" (p. 1006). Furthermore, students should be encouraged to investigate new forms of public-private partnerships in ways that avoid the adverse impacts of innovations that "increase the gap between the rich and the poor, amplify geopolitical tension, undermine environmental sustainability initiatives, and decrease health and well-being for significant numbers of people" (p. 1006). Table 6 below highlights three dimensions which content around developing responsible innovation should address.

Table 6. Content topics for Developing responsible innovations level of the DFA,according to (Maynard \& Garbee, 2019).

\begin{tabular}{|l|r|l|}
\hline Topic & Content: Elements of the topic & $\begin{array}{l}\text { Sample } \\
\text { references }\end{array}$ \\
\hline Tight coupling & $\begin{array}{l}\text { "The degree to which actions lead to unforeseen and } \\
\text { potentially catastrophic risks in tightly coupled systems has } \\
\text { been widely explored" (p. 493) }\end{array}$ & $\begin{array}{l}\text { Perrow (1999); } \\
\text { Taleb (2010) }\end{array}$ \\
\hline Latency & $\bullet \quad$ The "rapidly shifting landscape of consequences" (p. 494) & Maynard (2015) \\
\hline Value mismatch & $\begin{array}{l}\text { The "mismatch between drivers of innovation and societal } \\
\text { need" (p. 494) }\end{array}$ & Maynard (2015) \\
\hline
\end{tabular}

\section{Pedagogical content knowledge}

We propose in this paper that the PCK in design education should seek to foster the "management of ideas" in discourse and activities in design sessions. In addition to case-based teaching discussed in the previous section, the following inductive teaching and learning methods can be used:

- Inquiry learning: Prince \& Felder (2006) describe this method as one that starts with presenting students with "questions to be answered, problems to be solved, or a set of observations to be explained" (p. 127). The method requires formulating good questions (Lee, 2004), which will encourage students to contemplate conclusions in a guided way (Bateman, 1990; Staver \& Bay, 1987). Students can start working in small groups and gradually shift to more self-directed inquiry process (Lee, 2004). The method should improve critical thinking and intellectual growth, observing links and consequences of various interpretations of contexts (Smith, 1996; Haury, 1993).

- Discovery learning: This learning method is similar to inquiry learning but differs in that facts or concepts are "discovered" in the process. Therefore, the content should have a prescribed content for students to discover beyond just developing an educated opinion on a topic. The method is sometimes called "guided discovery" (Spencer \& Jordan, 1996), and in the context of design education and the problems described in this paper, this method can be effective in integrating different elements of the DFA framework, moving students simultaneously between knowing about understanding the technology and realizing the responsibility of its consequences.

\section{Conclusion and future work}

We propose the DFA as a framework that is based on pedagogical content knowledge in engineering design education. As we discussed in the beginning in many cases, relatively loose coupling and long time-constants between engineering solutions and emergent challenges have meant that it's been possible for ever-more advanced engineering approaches to keep ahead of a net loss in societal benefits. In effect, there has been an aggregate increase in quality of life over centuries around the world because we have had the ability to engineer new solutions to emerging challenges faster than the spread of these challenges has occurred. As a result, there are now deeply embedded assumptions within how we teach engineers 
and engineering that are predicated on a pattern of engineering solutions always outpacing emergent adverse consequences arising from previous solutions.

These assumptions have long glossed over the reality that aggregated societal benefits from engineering solutions often obscure localized adverse impacts. This is seen clearly where communities either do not have access to engineering breakthroughs because of poverty, discrimination, geopolitics or other factors, or where some communities pay a price for the benefits that others receive from technological advances. For instance, the benefits and consequences of climate change that is driven by human activities are highly unevenly distributed around the world. And it is becoming increasingly apparent that emerging technologies such as facial recognition and even medical interventions benefit some communities while disadvantaging others.

Despite this, it's been possible to gloss over such inhomogeneity in engineering benefits and costs in the past as the benefits have appeared on the whole to outweigh the costs - at least to the people who have been instrumental in making the assessments. However, we are increasingly facing a future where we can no longer rely on conventional wisdom to ensure that the benefits of engineering outweigh the adverse impacts. And because of this, there is an urgent need to revisit how engineering curricula address an informed and sophisticated understanding of the future, and how this impacts how engineers operate and build value within society.

To better-understand the urgency underpinning this need, there are many framings that can be used, including those associated with the fields of future-studies and science and technology studies. Here we take an approach that is informed by, but not constrained by, these and other areas of scholarship, to better-understand the nature of the challenge being faced. We have tried to emphasize the need for new design content, which should be carefully and fully coupled with effective pedagogy, to prepare students for designing the future based on emerging technologies. We intend to develop content and attempt delivering it to engineering design students based on the DFA framework.

\section{References}

"AAHE" [American Association for Higher Education] (2000). American Association for Higher Education Eighth Annual Conference on Faculty Roles and Rewards, February 3-6, 2000. Washington, DC.

Abell, S. K. (2007) Research on science teacher knowledge. In Abell, S. K. \& Lederman, N. G. (Eds), Handbook of Research on Science Education, New Jersey, USA: Lawrence Erlbaum Associates Inc

"ABET" [Accreditation Board for Engineering and Technology] (2019). Accreditation Criteria \& Supporting Documents. Available at: https://www.abet.org/accreditation/accreditation-criteria/ (Accessed February 2021)

Abell, S. K. (2008) Twenty years later: does pedagogical content knowledge remain a useful idea? International Journal of Science Education, 30(10): 1405 - 1416

Ali, H, \& Lande, M. (2019) "Data-Driven Decisions in Prototyping and Product Development: A Framework for Uncertainty and Decision-Making." Proceedings of the ASME 2019 International Mechanical Engineering Congress and Exposition. Volume 14: Design, Systems, and Complexity. Salt Lake City, Utah, USA. November 1114, 2019. V014T14A039. ASME. https://doi.org/10.1115/IMECE2019-11671

Ali, H., \& McKenna, A. F. (2020). Representations, between engineering design and engineering analysis. In ASEE Annual Conference and Exposition, Conference Proceedings (Vol. 2020, p. 1189). 
Andersen, C. U., \& Pold, S. B. (2014). "Post-digital books and disruptive literary machines.” Formules, 18, 164183.

Autor, D.; Mindell, D.; Reynolds, E. (2019) The Work of the Future: Shaping Technology and Institutions. Report: MIT Task Force on the Work of the Future. Cambridge, MA.

Baldwin R., \& Lopez-Gonzalez J. (2013). "Supply-Chain Trade: A Portrait of Global Patterns and Several Testable Hypotheses.” Working Paper 18957. Cambridge, MA: National Bureau of Economic Research.

Ball, D. L., Thames, M. H., \& Phelps, G. (2008). Content knowledge for teaching: What makes it special. Journal of teacher education, 59(5), 389-407.

Barrows, H. S., \& Tamblyn, R. (1980) Problem-Based Learning: An Approach to Medical Education, New York: Springer.

Bateman, W. (1990) Open to Question: The Art of Teaching and Learning by Inquiry, San Francisco: Jossey-Bass.

Bekki, J. M., Huerta, M., London, J. S., Melton, D., Vigeant, M., \& Williams, J. M. (2018). Opinion: Why EM? The Potential Benefits of Instilling an Entrepreneurial Mindset. Advances in Engineering Education, $7(1), \mathrm{n} 1$.

Blank, S. (2013). The four steps to the epiphany: successful strategies for products that win. K\&S Ranch.

Boud, D., \& Feletti G. (1997) The Challenge of Problem-Based Learning, 2nd ed., London: Kogan Page.

Boyer, E. L. (1990) Scholarship Reconsidered: Priorities of the Professoriate. Princeton, NJ: The Carnegie Foundation for the Advancement of Teaching.

Cross, N. (2000). Engineering Design Methods. Chichester, New York: John Wiley \& Sons.

Dahlgren, M.A. (2003) "PBL through the Looking-Glass: Comparing Applications in Computer Engineering, Psychology and Physiotherapy,” International Journal of Engineering Education, 19(5), pp. 672-681.

Davis, E.,A. (2003). Knowledge integration in science teaching: analyzing teachers' knowledge development. Research in Science Education, 34, pp. 21-53.

de Graaff, E., \& Kolmos, A. (2003) “Characteristics of Problem-Based Learning,” International Journal of Engineering Education, 19(5), pp. 657-662.

Delbecq, A. L. \& Weiss, J. (2000). “The business culture of silicon valley: a turn-of-the-century reflection” Journal of Management Inquiry, 9(1), 37-44.

DeLuca, V.W. (1991). Implementing technology education problem-solving activities. Journal of Technology Education, 2(2), 5-15.

Deng, Jia; Dong, Wei; Socher, Richard; Li, Li-Jia; Li, Kai; \& Fei-Fei, Li. (2009). "ImageNet: A Large-Scale Hierarchical Image Database.” Department of Computer Science, Princeton University. http://www.imagenet.org/papers/imagenet_cvpr09.pdf

Diefes-Dux, H. A., Moore, T., Zawojewski, J., Imbrie, P. K., \& Follman, D. (2004). A framework for posing openended engineering problems: Model-eliciting activities. In 34th IEEE Annual Frontiers in Education, FIE 2004. (pp. $3-8)$.

Dorst, K. (2011). The core of 'design thinking' and its application. Design studies, 32(6), 521-532.

Driel, J. H., Verloop, N. \& Vos, W.D. (1998). "Developing science teacher's pedagogical content knowledge." Journal of Research in Science Teaching, 35(6), pp. 673-695. 
Duch, B.J., Groh, S.E., \& Allen, D.E. (2001) The Power of Problem-Based Learning, Sterling, Virginia: Stylus.

Dym, C.L. (1994a). Engineering design: A synthesis of views. New Jersey: Cambridge University Press.

Dym, C.L. (1994b). Teaching design to freshmen: Style and content. Journal of Engineering Education, 83(4), 303310.

Dym, C., Agogino, A., Eris, O., Frey, D., \& Leifer, L. (2005). Engineering design thinking, teaching, and learning. Journal of Engineering Education, 94(1), 103-120.

"EIA" [Energy Information Administration] (2021). Total Energy: Recent Data. Washington: US Department of Energy. Available at: https://www.eia.gov/totalenergy/

Fenstermacher, G. D. (1978). 4: A Philosophical Consideration of Recent Research on Teacher Effectiveness. Review of research in education, 6(1), 157-185.

Fenstermacher, G. D. (1986). Philosophy of research on teaching: Three aspects. Handbook of research on teaching, 3(4), 37-49.

"Forbes" (2004). "Toshiba will have UPS fix its laptops." Forbes, April 27. Available at: https://www.forbes.com/2004/04/27/cx_ah_0427ups.html?sh=391224a92e99 (Accessed February, 2021)

Gess-Newsome, J. (1999). Pedagogical content knowledge: An introduction and orientation. In J. Gess-Newsome (ed.), Examining pedagogical content knowledge: The construct and its implications for science education. Dordrecht: Kluwer Academic

Green, T. F. (1971). The activities of teaching. New York: McGraw-Hill.

Grossman, P.L. (1990). The making of a teacher: Teacher knowledge and teacher education. New York: Teachers College Press.

Harris, J. G. \& Alter, A. E.. (2014). “California dreaming” Outlook: Issue 1. Accenture.

Hansen, S. (2012). "How Zara grew into the world's largest fashion retailer." The New York Times Magazine, November 9. Available at: https://www.nytimes.com/2012/11/11/magazine/how-zara-grew-into-the-worlds-largestfashion-retailer.html (Accessed February, 2021)

Haury, D. (1993) “Teaching Science through Inquiry,” ERIC/CSMEE Digest, ED359048.

Kardos, G. (1979). "Engineering Cases in the Classroom," Proceedings of ASEE National Conference on Engineering Case Studies.

Kardos, G.,\& Smith, C.O.. (1979) “On Writing Engineering Cases,” Proceedings of ASEE National Conference on Engineering Case Studies.

Keeley, L., Walters, H., Pikkel, R., \& Quinn, B. (2013). Ten types of innovation: The discipline of building breakthroughs. John Wiley \& Sons.

Kind, V. (2009). Pedagogical content knowledge in science education: perspectives and potential for progress. Studies in science education, 45(2), 169-204.

Knowles, J., Ettenson, R., Lynch, P., \& Dollens, J. (2020). Growth opportunities for brands during the COVID-19 crisis. MIT Sloan Management Review, 61(4), 2-6. 
Koen, B. V. (1994). Toward a strategy for teaching engineering design. Journal of Engineering Education, 83(3), 193-201.

Krishnamurthy, S. (2009). Case: Mozilla vs. Godzilla - the launch of the Mozilla Firefox browser. Journal of Interactive Marketing, 23(3), 259-271.

Kuratko, D. F. (2011). Entrepreneurship theory, process, and practice in the 21st century. International Journal of Entrepreneurship and Small Business, 13(1), 8-17.

Lee, V.S. (2004), Teaching and Learning through Inquiry, Sterling, Virginia: Stylus Publishing.

Lee, Kai-Fu. (2018) AI superpowers: China, Silicon Valley, and the new world order. New York: Houghton Mifflin Harcourt.

Lewis, T. (2005). Coming to terms with engineering design as content. Journal of Technology Education, 16(2), 3754.

London, J. S., Bekki, J. M., Brunhaver, S. R., Carberry, A. R., \& McKenna, A. F. (2018). A framework for entrepreneurial mindsets and behaviors in undergraduate engineering students: Operationalizing the Kern Family Foundation's" 3Cs". Advances in Engineering Education, 7(1), n1.

Lundeberg, M., Levin, B., \& Harrington, H. (1999). Who Learns What from Cases and How? The Research Base for Teaching and Learning with Cases, Mahwah, New Jersey: Lawrence Erlbaum Associates, Inc.

Lynn, Jr., L.E. (1999) Teaching and Learning with Cases, New York: Chatham House Publishers.

Magnusson, S., Krajcik, J. \& Borko, H. (1999). Nature, sources and development of pedagogical content knowledge for science teaching. In J. Gess-Newsome (Ed.), Examining pedagogical content knowledge: The construct and its implications for science education (pp. 95-132). Dordrecht: Kluwer Academic.

Malone, Thomas W. (2018). Superminds: The Surprising Power of People and Computers Thinking Together. New York: Little, Brown and Company.

Malone, Thomas; Rus, Daniela; \& Laubacher, Robert. (2020) Artificial Intelligence and the Future of Work. Research brief, RB17-2020: MIT Task Force on the Work of the Future. Cambridge, MA.

Maynard, A. D. (2014). Could we 3D print an artificial mind? Nature nanotechnology, 9(12), 955-956.

Maynard, A. D. (2015). Navigating the fourth industrial revolution. Nature nanotechnology, 10(12), 1005-1006.

Maynard, A. D., \& Garbee, E. (2019). Responsible innovation in a culture of entrepreneurship: A US perspective. In International Handbook on Responsible Innovation. Edward Elgar Publishing.

McMasters, J. H. \& Ford, S. D. (1990). An industry view of enhancing design. Journal of Engineering Education, 80(5), 526-529.

Mills, J. E., \& Treagust, D. F. (2003) “Engineering Education-Is Problem-Based or Project-Based Learning the Answer?" Australasian Journal of Engineering Education.

Mountz, Mick. (2011). “A Day in the Life of a Kiva Robot.” Wired Business Conference. https://www.youtube.com/watch?v=6KRjuuEVEZs

Mourdoukoutas, P. (2017). “Two problems with Whole Foods' business model.” Forbes, February 12. Available at: https://www.forbes.com/sites/panosmourdoukoutas/2017/02/12/two-problems-with-whole-foods-businessmodel/?sh=b69198648391 (Accessed February, 2021) 
"NAE" [National Academy of Engineering] (2015). Making Value for America: Embracing the Future of Manufacturing, Technology and Work. National Academy of Engineering Committee Report on Foundational Best Practices for Making Value for America. The National Academies Press: Washington, DC.

"NARST" [National Association for Research in Science Teaching] (2018). Pedagogical content knowledge: Teachers' integration of subject matter, pedagogy, students, and learning environment. National Association for Research in Science Teaching. https://narst.org/research-matters/pedagogical-content-knowledge

Neumann, K.E. (2003). The importance of redesign. The Technology Teacher, 63(3), 7-9.

Norman, G. R., \& Schmidt, H.G. (1992) "The Psychological Basis of Problem-Based Learning: A Review of the Evidence,” Academic Medicine, 67(9), pp. 557-565.

Norman, G; \& Schmidt, H. (1999) "Of what practical use is a baby? Perspectives on educational research as a scientific enterprise." Prof Educ Res Q. 20(3) 1, 3-5.

Norris, D. G. (1993). "Intel Inside" branding a component in a business market. Journal of Business \& Industrial Marketing.

Pahl, G. \& Beitz, W. (1996). Engineering design. New York: Springer.

Perrow, C. (1999), Normal Accidents: Living with High Risk Technologies. Princeton, NJ: Princeton University Press.

Peterson, C. R. (1990). The desegregation of design. Journal of Engineering Education, 80(5), 530-532.

Picker, Randal C. (2011). “The Razors-and-Blades Myth(s)," University of Chicago Law Review, 78(225).

Prince, M. J., \& Felder, R. M. (2006). Inductive teaching and learning methods: Definitions, comparisons, and research bases. Journal of engineering education, 95(2), 123-138.

Plumer, B. (2013). "China may soon stop flooding the world with solar panels." Washington Post, March 23. Available at https://www.washingtonpost.com/news/wonk/wp/2013/03/23/china-might-stop-providing-the-worldwith-cheap-solar-panels/ (Accessed February, 2021).

Porter M.E. (1998). The Competitive Advantage: Creating and Sustaining Superior Performance. 2nd Ed. New York: Free Press.

Rao, Anand; Palaci, Flavio; \& Chow, Wilson. (2019). This is what the world's CEOs really think of AI. World Economic Forum, Meeting of the New Champions, Dalian, People's Republic of China: https://www.weforum.org/agenda/2019/06/ai-will-shape-our-future-how-do-we-ensure-it-is-used-responsibly/

Remus, Dana; \& Levy, Frank. (2017). "Can Robots Be Lawyers? Computers, Lawyers, and the Practice of Law." Georgetown Journal of Legal Ethics, 30(3).

Roman, H. T. (2001). Technology education—Process or content? The Technology Teacher, 60(6), 31-33.

Russell, Stuart J.; \& Norvig, Peter. (2020). Artificial Intelligence: A Modern Approach, 4th ed. New York: Pearson.

Savage, E. \& Sterry, L. (1990). A conceptual framework for technology education. The Technology Teacher, 50(1), 6-11.

Schneider, F., \& Berenbach, B. (2013). A literature survey on international standards for systems requirements engineering. Procedia Computer Science, 16, 796-805. 
Schwab, K. (2015) Will the fourth industrial revolution have a human heart? World Economic Forum. Available at: https://www.weforum.org/agenda/2015/10/will-the-fourth-industrial-revolution-have-a-human-heart-and-soul/

(Accessed February 2021)

Shontell, A. (2015). "The Tech 'Titanic': How red-hot startup Fab raised \$330 million and then went bust” Business Insider, February 6. Available at: https://www.businessinsider.com/how-billion-dollar-startup-fab-died-2015-2 (Accessed February, 2021)

Shulman, L. S. (1986). Those who understand: Knowledge growth in teaching. Educational Researcher, 15(2), 4-14.

Shulman, L. (1987). Knowledge and teaching: Foundations of the new reform. Harvard educational review, 57(1), $1-23$.

Smith, D. (1996) A Meta-Analysis of Student Outcomes Attributable to the Teaching of Science as Inquiry as Compared to Traditional Methodology, Ph.D. dissertation, Temple University, Department of Education.

Spencer, J.A., \& Jordan, R.K. (1996) “Learner-Centred Approaches in Medical Education,” BMJ (British Medical Journal), Vol. 313, pp. 275-283.

Staver, J.R., \& Bay, M. (1987) "Analysis of the Project Synthesis Goal Cluster Orientation and Inquiry Emphasis of Elementary Science Textbooks," J. Research in Science Teaching, Vol. 24, pp. 629-643.

Taleb, N.N. (2010), The Black Swan: The Impact of the Highly Improbable, London and New York: Random House.

Tan, O.S. (2003) Problem-Based Learning Innovation, Singapore: Thomson.

Thomas, J.W. (2000) A Review of Research on Project-Based Learning, San Rafael, CA: Autodesk Foundation.

Turing, A. M. (1950). “Computing Machinery and Intelligence.” Mind 59 (236): 433-460.

Veal, W.R., Tippins, D.J. \& Bell, J. (1998). "The Evolution of Pedagogical Content Knowledge in Perspective Secondary Physics Teachers." Paper presented at the Annual Meeting of the National Association for Research in Science Teaching, San Diego, CA.

Wade, M. R., Macaulay, J., Noronha, A., \& Barbier, J. (2019). Orchestrating transformation: How to deliver winning performance with a connected approach to change. IMD, International Institute for Management Development.

Weiss, R. (2003) "Designing Problems to Promote Higher-Order Thinking," in D.S. Knowlton and D.C. Sharp, eds., Problem-Based Learning in the Information Age, New Directions for Teaching and Learning, \#95, San Francisco: Jossey Bass, Fall 2003, pp. 25-30.

West, H., Flowers, W., \& Gilmore, D. (1990). Hands-on design in engineering education: Learning by doing what? Journal of Engineering Education, 80(50). 560-564.

Westberry, R. (2003). "Selecting instructional strategies for technology education." Fifty-second yearbook of the Council of Technology Teacher Education. New York: McGraw-Hill, 101-115.

Xiong, Wayne; Wu, Lingfeng, Droppo, Jasha; Huang, Xuedong; \& Stolcke, Andreas. (2018). "The Microsoft 2017 Conversational Speech Recognition System." Proceedings IEEE International Conference on Acoustics, Speech and Signal Processing.

Zubrowski, B. (2002). Integrating science into design technology projects: Using a standard model in the design process. Journal of Teacher Education, 13(2), 47-70. 